\title{
Corrigendum: Morphine Binds Creatine Kinase B and Inhibits Its Activity
}

\section{OPEN ACCESS}

Approved by:

Frontiers Editorial Office,

Frontiers Media SA, Switzerland

*Correspondence:

Yannick Goumon

yannick.goumon@inserm.u-strasbg.fr

${ }^{\dagger}$ These authors have contributed equally to this work

¥Present Address: Alexis Laux-Biehlmann, Bayer AG, Research \& Development, Pharmaceuticals, Berlin, Germany

Specialty section: This article was submitted to Cellular Neurophysiology, a section of the journal Frontiers in Cellular Neuroscience

Received: 13 June 2019 Accepted: 14 June 2019 Published: 02 July 2019

Citation:

Weinsanto I, Mouheiche $J$, Laux-Biehlmann A, Delalande F, Marquette A, Chavant V, Gabel F, Cianferani S, Charlet A, Parat M-O and Goumon Y (2019) Corrigendum: Morphine Binds Creatine Kinase $B$ and Inhibits Its Activity.

Front. Cell. Neurosci. 13:292. doi: 10.3389/fncel.2019.00292

\begin{abstract}
Ivan Weinsanto $^{1 \dagger}$, Jinane Mouheiche ${ }^{1 \dagger}$, Alexis Laux-Biehlmann ${ }^{1 \dagger \neq}$, François Delalande ${ }^{2}$, Arnaud Marquette ${ }^{3}$, Virginie Chavant ${ }^{1,4}$, Florian Gabel ${ }^{1}$, Sarah Cianferani ${ }^{2}$, Alexandre Charlet ${ }^{1}$, Marie-Odile Parat ${ }^{5}$ and Yannick Goumon ${ }^{1,4 *}$

${ }^{1}$ Institut des Neurosciences Cellulaires et Intégratives, CNRS UPR3212 and Université de Strasbourg, Strasbourg, France, ${ }^{2}$ Laboratoire de Spectrométrie de Masse BioOrganique, IPHC-DSA, CNRS UMR7178 and Université de Strasbourg, Strasbourg, France, ${ }^{3}$ CNRS UMR7177 and Université de Strasbourg, Strasbourg, France, ${ }^{4}$ Mass Spectrometry Facilities of the CNRS UPR3212, Strasbourg, France, ${ }^{5}$ School of Pharmacy, University of Queensland, PACE, Woolloongabba, QLD, Australia
\end{abstract}

Keywords: morphine, complex, ligand-binding protein, creatine kinase, high affinity

\section{A Corrigendum on}

\section{Morphine Binds Creatine Kinase B and Inhibits Its Activity}

by Weinsanto, I., Mouheiche, J., Laux-Biehlmann, A., Delalande, F., Marquette, A., Chavant, V., et al. (2018). Front. Cell. Neurosci. 12:464. doi: 10.3389/fncel.2018.00464

In the published article, there was an error in affiliation "2." Instead of "Global Drug Discovery, Global Therapeutic Research Groups, Gynecological Therapies, Bayer Healthcare, Berlin, Germany", it should be "Laboratoire de Spectrométrie de Masse BioOrganique, IPHC-DSA, CNRS UMR7178 and Université de Strasbourg, Strasbourg, France.”

Additionally, the current address of one author has been added as a footnote and is denoted using “ $\ddagger$ ”

The authors apologize for this error and state that this does not change the scientific conclusions of the article in any way. The original article has been updated.

Copyright (®) 2019 Weinsanto, Mouheiche, Laux-Biehlmann, Delalande, Marquette, Chavant, Gabel, Cianferani, Charlet, Parat and Goumon. This is an open-access article distributed under the terms of the Creative Commons Attribution License (CC BY).

The use, distribution or reproduction in other forums is permitted, provided the original author(s) and the copyright owner(s) are credited and that the original publication in this journal is cited, in accordance with accepted academic practice. No use, distribution or reproduction is permitted which does not comply with these terms. 